\title{
EVALUATION METHODS OF PHYSICAL PRODUCTS OF PUPILS IN TERMS OF CREATIVITY AND OTHER SELECTED PARAMETERS
}

Jan KROTKÝ*, Západočeská univerzita v Plzni, Česká republika Petr SIMBARTL, Západočeská univerzita v Plzni, Česká republika

Přijato: 30. 4. 2016 / Akceptováno: 5. 7. 2016

Typ článku: Teoretická studie

DOI: $10.5507 /$ jtie.2016.021

Abstract: The authors of the article deal with the question of evaluating physical products from several viewpoints and they search for a possibility how to implement the evaluation of creativity. A change like this assumes a modern and innovative approach to education. Information was gained from the research activity, which included mainly foreign sources in the form of published research results and conclusions of educational organizations.

The presented results will be used for further research on new evaluation methods corresponding to the current trends in the field of technical education at primary schools. These methods may be subsequently tested in practice.

Key words: creativity, innovation, World of Work, Man and the World of Work primary schools, technical education.

\section{METODY EVALUACE FYZICKÝCH VÝROBKŮ ŽÁKŮ Z HLEDISKA PROJEVENÉ KREATIVITY A DALŠÍCH VYBRANÝCH PARAMETRŮ}

Abstrakt: Autoři se v článku zabývají otázkou hodnocení fyzických výrobki̊ z několika hledisek a hledaji možnosti implementace hodnoceni kreativni tvorby. Tato změna předpokládá nové a inovativní pojetí výuky. Ziskané informace pochází z rešeršní činnosti, do které jsou zahrnuty zejména zahraniční zdroje v podobě publikovaných výsledků výzkumů a závérů vzdèlávacích organizací.

Předložené výsledky budou sloužit $k$ dalšimu výzkumu nových evaluačních metod korespondujicich s aktuálními trendy v oblasti technického vzdělávání na základních školách. Tyto metody mohou být následně v praxi testovány.

Klíčová slova: kreativita, inovace, World of Work, Člověk a svět práce, základní škola, technické vzdělávání.

*Autor pro korespondenci: conor@kmt.zcu.cz 


\section{1 Úvod}

Vzdělávací oblast Člověk a svět práce integruje celou řadu technických, přírodovědných a společenskovědních oborů. V rámci dotazníkového institucionálního šetření bylo zjištěno, že se jedná zejména o matematiku, fyziku, chemii, ale také geografii nebo dokonce výtvarnou a hudební výchovu v odpovídajících podílech. Šetření probíhalo analýzou obsahů vzdělávací oblasti Člověk a svět práce České republiky, Slovenska a Německa. (Mach, Simbartl, \& Krotký, 2015).

V České republice se velká část obsahu realizuje v předmětu Technická výchova, který je zaměřen zejména na získávání praktických dovedností. Prioritními tématy jsou Provoz a údržba domácnosti, Práce s technickými materiály, Design a konstruování a Svět práce (v ČR většinou povinné téma pro poslední ročník ZŠ). (Mach, Simbartl, \& Krotký, 2015). Před rozsáhlými změnami $v$ českém školství danými změnou režimu po roce 1989 probíhaly aktivity v oblasti předmětu technické výchovy zejména jako práce $\mathrm{v}$ dílně nebo na pozemku. Prioritou tehdejšího školství bylo vychovávat především budoucího dělníka do továren. Žáci si při výuce měli osvojit různé technologie zpracování, seznámit se s nářadím, pracovat rychle a přesně. Tento systém byl částečně i dán i historicky neexistujícím technickým a výpočetním zázemím jaké máme k dispozici dnes. Prakticky můžeme říci, že neexistence „fyzického kreativního produktu“ obecně včeském školství za minulého režimu byla dána jak politickými tak i technickohospodářskými důvody. Dnešní školství je ale mnohem více zaměřené na rozvoj a utváření žáka jako jedince v kontextu společnosti. Od žákủ požadujeme osobitý kreativní př́istup při řešení problémových situací, hledání nových možností a inovací. Ideálním stavem je, když dnešní absolvent základní školy nejenom ovládá technologie zpracování různých materiálů a podobně, ale také chápe proces výroby tzv. „od myšlenky $\mathrm{k}$ výrobku“. Učitel technické výchovy mimo jiné $\mathrm{v}$ této situaci řeší $\mathrm{v}$ rámci edukačního procesu problém, jakým způsobem a podle jakých parametrů hodnotit fyzický tedy ten hmatatelný produkt žáka.

Pokud žák vytváří produkt podle předem známé dokumentace, přesného zadání, učitel i žák ví, jak má tento produkt přesně vypadat. Hodnocení takovéhoto produktu spočívá zejména ve finální kontrole rozměrů, či předepsaného zpracování (např. drsnost, kvalita opracování atd.) nebo $\mathrm{v}$ subjektivním hodnocení technologického procesu zpracování (metodou průběžného pozorování žáka). Jakým způsobem má ovšem hodnotit učitel produkt vzniklý kreativním procesem? V tomto případě na začátku existuje pouze jisté problémové zadání a žák nebo tým žákủ jej musí řrešit. Učitel přesně neví, jaké řešení nebo jaký produkt v průběhu výuky vznikne, z jakého bude materiálu, jaké technologie žák použije nebo jak dlouho bude výrobek vytvářet. Měřítkem může být právě užitečnost nebo funkčnost produktu či míra projevené kreativity v kontextu s inovací.

Primárním cílem této studie je zmapovat oblast evaluace produktu s ohledem na projev kreativity a připravit teoretická východiska k připravovanému výzkumu. Uvedené zdroje a směry výzkumu budou zásadní pro další zpracování v připravované tematické publikaci. Sekundárním cílem je upozornit na nutnost změny př́istupu v oblasti technického vzdělávání na základních školách v souvislosti s aktuálními trendy a vývojem společnosti. 


\section{Použité metody}

\section{Formulace tématu}

Požadavek na rešerši tématu hodnocení kreativního produktu žáků v oblasti technických činností vzniknul na základě dílčích výsledků institucionálního šetření mezinárodního projektu s názvem World of Work. Šetření v tomto projektu mapovalo mimo jiné i priority v komplexním hodnocení činnosti žáků při aktivitách spadajících do vzdělávací oblasti Člověk a svět práce. Dle výsledků je největši důraz při hodnocení kladen učiteli zejména na „Tvořivost, schopnost vytvářet a realizovat vlastní náměty“. Ovšem dle dalších indicií nejsou nástroje pro objektivní hodnocení takto zaměřených výstupů na úrovni základní školy implementovány. (Draxal, 2016a) Téma koresponduje s názvem článku.

Definice klićových slov

Rešerše v úzké oblasti, jakým je hodnocení kreativního produktu žáků vyžaduje detailní specifikaci vstupních parametrů pro vyhledávání relevantních informací. Obecné oblasti tématu vyplývají z charakteru zkoumané problematiky, kdežto konkrétní oblasti prezentují již hlavní směry našeho zájmu.

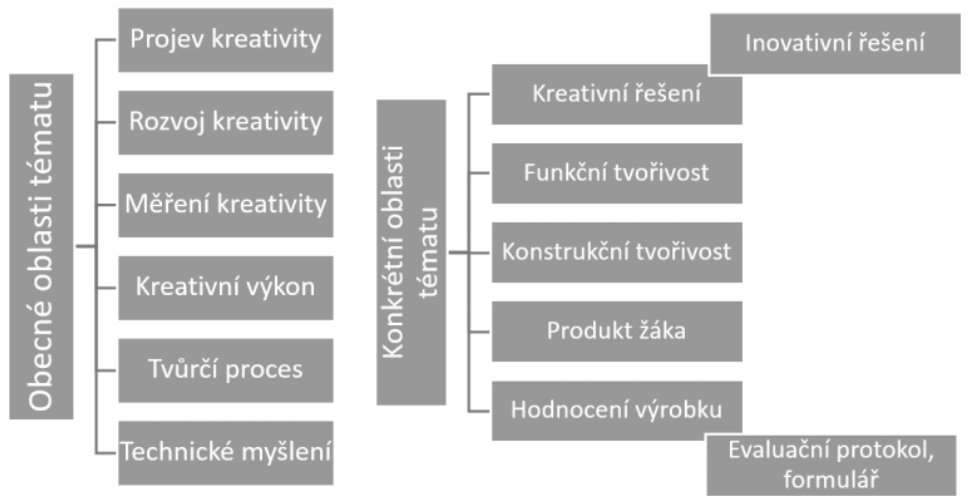

Obr. č. 1: Obecné a konkrétní oblasti zpracovávaného tématu

\section{Vymezení zdrojů informací}

V rámci prováděné rešerše materiálů jsme se soustředili především na články a publikace zveřejněné $v$ anglickém jazyce a zároveň na publikace zejména zahraničních autorů. Ze strany českých autorů existuje celá řada článků a publikací věnujících se zejména obecné oblasti tématu (napřr. Maňák, Lokšová, Lokša atd.). V oblasti více směřované do techniky, či př́mo do technické výchovy můžeme zmínit prínos slovenské autorky M. Kožuchové nebo české autorky J. Honzíkové. Zahraničních autorů postihujících byt' i okrajově oblasti našeho zájmu je pochopitelně více. Jako relevantní přicházejí v úvahu zejména práce Donalda Treffingera nebo starší díla Mela Rhodese (70. léta).

Typy dokumentů nebyly omezovány, ovšem soustředili jsme se primárně zejména na časopisecké články a monografie. Časopisy jako Creativity Research Journal nebo Thinking Skills and Creativity ve svém rozsahu postihují široké spektrum informací k tématu. 
Nicméně ukázalo se, že i časopisy směřované primárně do psychologie jako např́ílad Psychology Science nebo Genetic, Social and General Psychology Monographs se př́ležitostně zabývají obecnými tématy kolem kreativity také. Pro vyhledávání odpovídajících článků zaměřených ideálně do konkrétních oblastí našeho zájmu jsme proto zvolili vyhledávače a databáze typu Google Scholar nebo Web of Science či Scopus, vyhledávání dle klíčových slov korespondujících s tématem.

Komparací informací z nalezených zdrojů rešerše vyústila mimo jiné v detailnější analýzu práce Arthura Cropleye (University of Hamburg) a Davida Cropleye (University of South Australia) jejichž práce v konkrétní oblasti tématu se ukazuje pro další náš plánovaný výzkum stěžejní a vhodná pro navázání. Dedukcí byly stanoveny v článku uvedené závěry v podobě detailních směrů dalšího možného výzkumu a požadavků na inovaci výuky technicky orientovaných předmětů na základních školách v České republice.

\section{Inovace a tvořivost}

Inovaci můžeme $\mathrm{v}$ našem kontextu chápat jako realizaci nového nebo podstatně zlepšeného produktu, služby nebo procesu, který vytváří hodnotu pro podnikání nebo státní správu. „Tvořivost hraje důležitou roli v inovačním procesu: je to o tom, jak najít nápady na nové produkty a jak tyto budou oceněné na cílených trzích.“ (Cropley, Kaufman, \& Cropley, 2011). Kreativita je tedy motorem inovace. Linda Naiman uvádí, že kreativita je „zásadní součást inovační rovnice a že neexistuje inovace bez kreativity“. Společným jmenovatelem tvořivosti a inovace je tedy vytvoření hodnoty. (Naiman, 2014)

Autorka dále varuje před problémy $\mathrm{v}$ podobě podpory jednotnosti a určité standardizace výkonu žáků a slabé podpoře kreativního procesu ve vyučování. (Naiman, 2012; ceskaskola.cz, 2015). Učitel respektuje specifika každého žáka a zohledňuje v jeho výkonu kromě projevené kreativity celou řadu dalších faktorů. Pro výchovně vzdělávací proces je důležité, zda je možné se $\mathrm{v}$ procesu kreativní tvorby zlepšovat. Může učitel nějakým způsobem prrispět $\mathrm{k}$ výraznějším projevům kreativity u žáků? $\mathrm{K}$ tomuto tématu zpracovali autoři Scott G., L. E. Leritz \& M. D. Mumford (2004) kvantitativní meta analýzu vyhodnocení asi 70 vzdělávacích programů pro rozvoj kreativity a zjistili, že v určitých př́ípadech k rozvoji kreativity opravdu dochází (zvyšování kreativního výkonu). (Scott, Leritz, Mumford, 2004) Dle našeho názoru může tedy i učitel na základní škole volbou vhodných metod, zadáním i organizací výuky kreativitu nejen podporovat, ale také ji i rozvíjet. Aby ji mohl ovšem rozvíjet, musí se zaměřit na všechny tři komponenty kreativity (Amabile, 1998):

- Odbornost (technické a technologické znalosti a dovednosti)

- Kreativní myšlení (zejména rozvoj dovedností, práce s představou, vizualizací)

- Motivace

Jak je zde vidět, tak je důležitá i samotná odbornost žáků. Tedy stále učit žáky základní dovednosti s náŕadím a technologické postupy aj. Bez těchto znalostí a dovedností nemůže docházet k rozvoji kreativity a vzniku kreativního a inovativního produktu. Obecně je pro rozvoj kreativity důležitý i samotný „tvořivý styl řizení“ - styl vedení výuky (Št'áva, 1997) orientovaný výrazně na žáka a podpora více směrné komunikace nebo aktivity žáků. Styl vedení výuky je evaluačním protokolem kreativního produktu obtížně uchopitelná oblast a přitom má dle našeho názoru výrazný vliv na výsledek tvořivého procesu. 


\section{Měření a projevy kreativity}

Metody měření samotné kreativity uvádí přehledně např́íklad autoři Callahan, Tomlinson, Hunsaker, Scott, Bland, \& Moon, (1995) nebo (Honzíková, 2015). V našem národním prostředí se setkáme zejména $\mathrm{s}$ „Urbanovo testem tvořivého myšlení“ nebo $\mathrm{s}$,Torranceho testem kreativity“. Tyto testy jsou relativně jednoduché na vyhodnocení a četné výzkumy jimi realizované poskytují širokou základnu výsledků. Testy zjišt’ují úroveň kreativity u jedince, ovšem nelze je použít pro měření fyzického produktu kreativní činnosti.

Měřením kreativity se také zabývá Donald Treffinger at al. (2002), který popsal a definoval čtyři úrovně rozvoje kreativity používané v některých popisovaných nástrojích evaluace produktu. Sám zdůrazňuje, že jeho charakteristika je ,dynamická a nikoliv statická, lidé se mění a rostou, reaguji odlišně $i$ v rüzných oblastech a na základě rüzných mènících se okolnost $i^{\prime \prime}$. (Treffinger at al., 2002, str. 75)

Charakteristika úrovní rozvoje kreativního projevu - výkonu u jedince (Treffinger at al., 2002, str. 49, 62):

a) Bez evidentního projevu (Not Yet Evident) - u jedince se aktuálně neprojevují žádné vlastnosti nebo chování v souladu s definicí kreativity. (nejde o posuzování schopností, ale o posouzení kreativního výkonu, kreativita se u posuzované osoby může projevit i později).

Role žáka: budování potřební základny pro rozvoj kreativity.

Role učitele: směrování, řízení procesu.

b) Formující se projev (Emerging) - u jedince se projevují náznaky kreativního projevu. Projev je nekonzistentní.

Role žáka: rozvíjení a cvičení kreativních dovedností

Role učitele: trénování, ř́zené aktivity.

c) Projevující, vyjadřující projev (Expressing) - stabilní projevy kreativity, prokázaná vysoká kvalita kreativního výstupu (např. výrobku, pozn. aut.)

Role žáka: uplatnění nástrojů a dovedností pro kreativní řešení reálného problému

Role učitele: podpora žáka, spoluřízení procesu.

d) Excelentní projev (Excelling) - jedinec dosahuje ve své kreativní tvorbě vynikajících - excelentních výsledků, produkt kreativity lze charakterizovat jako kvalitní a originální.

S uvedenou analýzou úrovní rozvoje kreativního projevu dle Donalda Treffingera at al. (2012) pracuje i Angela Mastracci ve svém výzkumu publikovaném v článku s názvem Presentation of Assessment tools for evaluating creative learning. Mastracci přiřazuje kvalitativním popisem k jednotlivým úrovním fyzické i kvalitativní indikátory, které musí hodnocené objekty splňovat a to pro každou definovanou úroveň rozvoje kreativního projevu. (Mastracci, 2011, str.12) 
Obecně je kvalitativní popis dosažených skutečností nebo vlastností problematický a to zejména z hlediska vzájemné komparace takto popisovaných výsledků. Model kreativity jak ho definoval Mel Rhodes v roce 1961, stojí na třech základních pilírích v podobě osoby (Person), procesu (Proces) a produktu (Product). Nad těmito pilíři existuje ještě prostor (Place, Environment), který je důležitým stimulem kreativity. (Rhodes, 1961) Angella Mastracci dokázala, že každý $\mathrm{z}$ těchto tří základních pilířu můžeme diferencovat podle projevovaných úrovní kreativity. Z hlediska hodnocení produktu, dle projevované kreativity je pro nás relevantní sestavení a ověření evaluačního protokolu schopného dosažené úrovně zachytit. Jednotlivé úrovně kreativního projevu jsou jejím protokolem škálovatelné a zachycují tak i míru naplnění. (Mastracci at al., 2012, str. 47)

Model kreativity dle Mela Rhodese (1961) doplnila o další prvek a některé vztahy Susanne Filteau (2012). Tímto prvkem je čas nebo také doba (Period). Kreativní proces, produkt, myšlení nebo osoba existují vždy v nějakém časovém úseku a jsou tímto ovlivněny. Doba spolu s prostorem mají zásadní vliv na zmiňované základní piliŕře kreativity. (Filteau, 2012, str. 2) Nedostatek času má na kreativní výkony negativní vliv (Amabile, at al. 2002; Brady \& Auslen, 2012; Adams, 2001). Podobně mají negativní vliv i depresivní, nebarevné, obecně nehygienické nebo jednotvárné pracovní prostředí (Makhmalbaf \& Yi-Luen Do, 2007; Alimardani \& Soheili, 2014; apod.)

\section{Hodnocení kreativního produktu}

Kreativní produkt můžeme identifikovat jako výsledek tvůrčího procesu. Produkt může mít celou řadu hmatatelných i nehmatatelných forem. Kreativní produkt je průnikem něčeho nového, originálního, funkčního a přizpůsobeného aktuálním podmínkám nebo požadavkům. (Filteau, 2012) S požadavkem novosti a originálnosti, př́ipadně efektivity se ztotožňují v oblasti posuzování kreativního produktu také další autoři (Cropley, Kaufman, \& Cropley, 2011). Tito autoři nicméně naproti tomu uvádí, že kreativní produkt je spíše „,ztělesněním kreativity a inovaci" než že byl pouhým produktem tvưrčího procesu, tak jak k němu budeme prristupovat z velké části my. (Cropley, Kaufman, \& Cropley, 2011) Faktory, které se nejvíce uplatňují při samotné diagnostice tvořivosti, determinovala přehledně např. Jolana Laznibatová (2007) jako fluenci (plynulost), flexibilitu (pružnost), originalitu (novost) a elaboraci (vypracování). Evaluační protokol pro hodnocení kreativního produktu by měl všechny oblasti prezentované uvedenými faktory obsahovat. (viz např. protokol SPAF (Reis \& Renzuli, 2004, str. 52)) Podobně rozebírají zmiňované faktory také autoři Maňák (2001) nebo Pecina (2008) a navíc pracují i faktorem senzitivity (citlivosti odhalovat „skrytý“ problém nebo faktorem redefinice (využívat objekty jinak a k něčemu jinému, než pro co byly původně stvořeny).

Obecně existují tři př́stupy měření kreativity produktu (Cropley, Kaufman, \& Cropley, 2011):

- hodnocení odbornými hodnotiteli

- $\quad$ hodnocení dle předem daných kritérií

- hodnocení historického dopadu daného produktu

Možnost hodnocení odbornými hodnotiteli je dle našeho názoru značně subjektivní a do jisté míry se prolíná s kriteriálním hodnocením. Taková to kritéria pro hodnocení 
vznikají u erudovaných hodnotitelů, kteří si je podvědomě sami vytváŕí. Slabá stránka tohoto prístupu spočívá $\mathrm{i} v$ omezeném počtu takových to hodnotitelů každého produktu (učitel zpravidla hodnotí produkt sám), př́ípadně ve velké diferenci v hodnocení. Objektivitu může přinést i za cenu určité neodbornosti tzv. sociální filtrování, které známe z hodnocení online vzdělávacích materiálů. (Krotký, 2015)

Hodnocení historického dopadu produktu principiálně těží především z potřebnosti produktu a jeho uplatnění na trhu. Tento nejobjektivnější ukazatel úspěchu produktu, ovšem nemusí korespondovat s mírou uplatněné kreativity. Vítězí na trhu vždy ty produkty, které jsou výsledkem kreativní inovace?

Evaluační protokoly kreativního produktu jak je vytvořila Angella Mastracci (2012) byly vytvářeny $\mathrm{s}$ cílem zachytit nuance kreativního projevu, ovšem ne př́mo u fyzického produktu. Přesto si myslíme, že je její evaluační protokol po revizi kvalitativních indikátorů modifikovatelný pro hodnocení fyzických produktů, výrobků žáků. Cropley, Kaufman, \& Cropley (2011) připomínají nedostatek studií a výzkumů zaměřených právě na hodnocení kreativního produktu ve své hmotné fyzické podobě - výrobku. Uvedení autoři se systematicky snaží tuto mezeru zaplnit, ovšem sběr produktů pro relevantní výzkum je časově i materiálové náročný, výroba produktu vyžaduje technologie i zázemí pro maximální podporu kreativní práce. (Amabile, 1998)

Funkční tvořivost (functional creativity) je pojem se kterým začal pracovat Cropley \& Cropley (2005) a odděluje jím pohled na hodnocení produktů tvořivosti v podobě např́klad grafických nebo textových prací a produktů - výrobků. Uvedení autoři předkládají myšlenku, že nemůže existovat kreativní produkt bez jeho vlastní účinnosti. Pokud např́ílad student vytvoří nový model vozu a na střechu mu umístí nějaký nestandardní prvek, je to projev kreativity nebo spíše nedostatku odborných znalostí?

Cropley \& Cropley (2005) ve svém evaluačním protokolu zavádí kriteriální čtyřstupňové hodnocení, které odráží právě onu společenskou prospěšnost - účinnost kreativního produktu. V tomto ohledu můžeme spatřovat jistou analogií v protokolu Angelly Mastracci (2012) těžící z prací Donalda Treffingera (Treffinger at al., 2002), ovšem bez zmíněných produktově problematických kvalitativně definovaných indikátorů.

Sally M. Reis \& Joseph S. Renzuli (2004) s úspěchem použivají pro hodnocení produktu relativně jednoduchý evaluační protokol SPAF (Student Product Assessment Form) sestávající se ze základních devíti definovaných faktorů (např. zaměření - identifikace problému, rozmanitost použitých zdrojů atd.) a sedmi dalších faktorů jako originalita nápadu, využitý čas, zpracování detailů atd. Hodnocení položek spočívá v bodové škále a vypočitává se celkový rating. (Reis \& Renzuli, 2004, str. 52) Takto sestavený evaluační protokol je pro učitele dobře uchopitelný a ve specifické školní praxi použitelný. Umožňuje relativně rychlé a objektivní hodnocení, se kterým učitel může dále pracovat (zohledňovat další vývoj žáka, porovnávat s dalšími výsledky atd.) Kompletní evaluační protokol SPAF je součástí zde odkazovaného článku původních autorů.

\section{Závěr}

V kontextu popisu rozvoje kreativity musíme souhlasit sčástí textu manifestu uveřejněného na webu ceskaskola.cz, jehož součástí je v bodě sedm i toto prohlášení: „Je-li výzvou pro naše školy a vlády připravovat studenty, kteři vynikaji kreativitou a inovativním 
přistupem, a nikoliv bezmyšlenkovitým memorováním a odřikáváním starých idejí, pak $i$ každé využiváni nových technologii ve vzděláváni musí směrovat $k$ podpoře kreativity a inovativního př́stupu. Školy by neměly použivat počitače $k$ „práci“ s predpřipravenými parametry a predem předepsanými výsledky.“ (ceskaskola.cz, 2015) Zejména poslední věty jsou v kontextu přicházející 4. průmyslové revoluce známé pod heslem Průmysl 4.0. Důsledkem digitalizace a robotizace budou některé současné profese existenčně ohroženy, př́padně bude nutná jejich obsahová a společenská revize. Česká republika je země zaměřená na průmysl a ještě stále můžeme říci, že zde vznikají produkty s vysokou přidanou hodnotou. Vychováváme žáky, absolventy právě pro tento měnící se segment ekonomiky. „Digitální transformace $v$ podobě průmyslu 4.0 přinese výzvu pro mnoho zaměstnanců. Zvýšené potřeby budou směrovány zejména na rozvoj kreativnich pracovnich procesů, jako je strategické plánování nebo výzkum a vývoj“. (Industry 4.0, 2015, str. 14)

Podpora a rozvoj kreativity u studentů je jedna z priorit našeho školství, aby úspěšně obstálo v rychle měnícím se světě. Evaluace produktu kreativní činnosti umožňuje aktivně ř́dit a individualizovat rozvoj žáků.

„V budoucnu budou muset výrobni podniky věnovat větši pozornost rozvoji kompetencí jejich zaměstnanců a nabirat digitálně kompetentní pracovni silu“. (Industry 4.0, 2015, str. 15)

Úkolem tohoto článku bylo primárně zmapování možnosti systémové změny hodnocení ve výuce technické výchovy za účelem efektivní podpory rozvoje kreativity u studentů. V blízké době bude probíhat další fáze projektu spočívající ve zjištování dalších metod hodnocení tvorby studentů. Důvody zmiňované v úvodu nás nutí domnívat se, že k podpoře kreativity $\mathrm{v}$ technicky orientovaných předmětech na základních školách $\mathrm{v}$ ČR dochází minimálně. Tento předpoklad bude nutné ověřit detailním šetřením $\mathrm{v}$ terénu př́mo mezi učiteli technické výchovy. Ve výzkumu se ale zaměříme především na oblast hodnocení fyzických výrobků. Pokud se bude hodnocení učitelů podle předpokladu zaměřovat převážně na „finální kontrolu rozměrů a provedení“ např. (Draxal, 2016), budou nás zajímat zejména příčiny tohoto stavu. Hlavní hypotézy mohou být formulovány např́klad následovně:

- „Vyučující hodnotí žáky především finální kontrolou rozměrů, provedení výrobku, protože považuje toto hodnocení za nejobjektivnější.",

- „Vyučující hodnotí žáky především finální kontrolou rozměrů, provedení výrobku, protože časová dotace neumožňuje využívat metody a styl výuky pro efektivní rozvoj kreativity u dětí.“

Po objasnění aktuálního procesu hodnocení produktu žáka, budeme další výzkum směřovat právě do vývoje metod objektivního hodnocení kreativní tvorby žáků s ohledem na specifika našeho národního prostředí.

Všechny odkazované studie a jejich závěry jsou dostupné na uvedených zdrojích. 


\section{Literatura}

Adams, J. L. (2001). Conceptual blockbusting. Cambridge: Perseus Publishing.

Alimardani, K., \& Soheili, J. (2014). On the effect of physical attributes of classroom environment on the creativity of educable mentally retarded students. In: International Journal of Architectural Engineering \& Urban Planning, Vol. 24, No. 1.

Amabile, T. (1998). How to Kill Creativity. Harvard Business Review, September-October Issue. Dostupné z: https://hbr.org/1998/09/how-to-kill-creativity

Amabile, T., Hadley, C. N., \& Kramer S. J. (2002). "Creativity Under the Gun.” In: Special Issue on The Innovative Enterprise: Turning Ideas into Profits Harvard Business Review 80, $8,52-61$.

Brady, R., \& Auslen L. (2012). Study Reveals Global Creativity Gap. Adobe Systems Incorporated. San Jose. Dostupné z: Study Reveals Global Creativity Gap

Callahan, C. M., Tomlinson, C. A., Hunsaker, S. L., Bland, L. C., \& Moon, T. R. (1995). Instruments and evaluation designs used in gifted programs (Research Monograph 95132). Storrs: University of Connecticut, The National Research Center on the Gifted and Talented.

Cropley, D. H., \& Cropley, A. J. (2005). Engineering creativity: A systems concept of functional creativity. In: J. C. Kaufman and J. Baer (Eds.), Creativity across domains: Faces of the mus. 169-185.

Cropley, D. H., Kaufman, J. C. \& Cropley, A. J. (2011). Measuring Creativity for Innovation Management. doi: 10.4067/S0718-27242011000300002.

Draxal, L. (2016). Praktická část diplomové práce Rozvoj technických kompetencí žáka. In Olympiáda techniky Plzeň 2016 : sborník př́spěvků z mezinárodní studentské odborné konference. Plzeň, Západočeská univerzita

Draxal, L. (2016a). Rozvoj technických kompetencí žáka. Diplomová práce. Plzeň, Západočeská univerzita v Plzni

Honzíková, J. (2015). Creativity and Skills in School Environment. Saabrucken: LAP LAMBERT Academic Publishing.

Industry 4.0. (2015). Evaluation methods of physical products of pupils in terms of creativity and other selected parameters. Zurich: The Creative Studio at Deloitte. Dostupné z: http://www2.deloitte.com/content/dam/Deloitte/ch/Documents/manufacturing/ch-enmanufacturing-industry-4-0-24102014.pdf

Krotký, J. (2015). Nové formy tvorby multimediálnich učebnic. Plzeň. Disertační práce. Západočeská univerzita, Fakulta pedagogická.

Laznibatová, J. (2007). Nadané dieta jeho vývin, vzdelávanie a podporovanie. Bratislava, IRIS

Mach, P., Simbartl, P. \& Krotký, J. (2015). World of Work - Aktivita 1 Pri̊zkum Vyhodnoceni dotazníkového šetření. ZČU v Plzni. Dostupné z: http://www.world-ofwork.eu/sites/default/files/documents/Research_report_CZ.pdf

Makhmalbaf, A., \& Yi-luen Do, E. (2007). Physical environment and creativity: comparing children's drawing behavior at home and at the bookstore. In: IASDR07, College of Architecture, Georgia Institute of Technology. Dostupné z: https://wiki.cc.gatech.edu/designcomp/images/9/95/IASDR-phys-env-creative.pdf Maňák, J. (2001). Stručný nástin metodiky tvořivé práce ve škole. Brno, Paido 
Manifesto 15. (2015). Evoluce vzdělávání. Česká škola. Dostupné z: http://www.ceskaskola.cz/2015/03/manifesto-15-evoluce-vzdelavani.html

Mastracci at al. (2012). Échange de pratiques portant sur l'évaluation des apprentissages de la créativité en conception graphique. Montréal: Cégep Marie-Victorin, CCNB - Campus de Dieppe.

Naiman, L. (2012). The Global Creativity Gap. Creativity at Work. Dostupné z: http://www.creativityatwork.com/2012/04/23/the-global-creativity-gap/

Naiman, L. (2014). What is Creativity?. Creativity at Work. Dostupné z: http://www.creativityatwork.com/2014/02/17/what-is-creativity/

Pecina, P. (2007). Tvořivost ve vzdělávání žáků. Brno, Masarykova univerzita

Reis, S. M., \& Renzuli, J. S. (2004). The Assessment of Creative Product in Programs for Gifted and Talented Students. In: Carolin M. Callahan, Program Evaluation in gifted education, Corwin press, A sage Publication Comp. Thousand Oaks, California, USA.

Rhodes, M. (1961). An Analysis of Creativity. In: The Phi Delta Kappan, 42, 7, 305-310.

Scott, G., Leritz, L. E., \& Mumford, M. D. (2004). The Effectiveness of Creativity Training: A Quantitative Review. In: Creativity Research Journal, 16, 4, 361-388. Dostupné z: http://www.gettingsorted.com/Scott_et_al_2004_Creativity_Training.pdf

Štáva, J. (1997). Lze tvořivost naučit? In Tvořivost učitele k tvořivosti žáků: sborník $\mathrm{z}$ celostátního semináře $\mathrm{k}$ problematice tvořivosti v práci učitele a žáka. Brno, Paido

Treffinger, D. J., Young, G. C., Selby, E. C., \& Shepardson C. (2002). Assessing Creativity: A Guide for Educators. The national research center on the gifted and talented. Dostupné z: http://nrcgt.uconn.edu/wp-content/uploads/sites/953/2015/04/rm02170.pdf 